\title{
PURGING THE PAST: THE CURRENT STATE OF LUSTRATION LA WSIN THE FORMER COMMUNIST BLOC
}

\author{
MARK S. ELLIS \\ I \\ INTRODUCTION
}

Following the 1989 "democratic revolutions," there was an immediate, though not surprising, backlash against former communist regimes. Throughout E astern E urope, it was widely perceived that former Communists could not be trusted to carry out democratic reforms. In this context, an important debate surfaced that focused on questions of culpability for crimes committed by former Communist regimes. Options ranged from providing amnesty or pardon, prosecuting individuals, or outlawing the Communist Party. Indeed, many of the newly constituted governments reacted swiftly by outlawing the Party, prosecuting anyone deemed to have had connections to the Party or the Secret Police, or restricting those individuals from certain government and non-government posts.

Lustration ${ }^{1}$ laws, though controversial, remain the most commonly used device for screening and "prosecuting" former Communist leaders, candidates for office, and selected public employees. These laws, which generally rely on information contained in Secret Police files, are used to determine whether suspected individuals collaborated with the former state security service. The international community has generally opposed the lustration process. ${ }^{2}$ This article presents a brief overview of the current status of such laws and regulations in the former Communist B loc.

II

\section{LUSTRATION LAWS}

Political partisanship greatly influences the introduction and adoption or failure of lustration legislation. This is apparent in a comparison of countries of the region in which former communists continue to dominate the political

Copyright (c) 1997 by L aw and Contemporary Problems

*Executive Director, Central and East European Law Initiative ("CEELI"), A merican Bar A ssociation.

1. The word "lustration" is derived from the Latin "lustratio" meaning "put light on, or illuminate; purification by sacrifice or by purging." J irina Siklova, L ustration or the Czech Way of Screening, 5 E. EUR. CONST. REV. 57 (Winter 1996).

2. See Paul Goble, Analysis From Washington: Toward Collective Innocence? (May 1996) $<$ <ttp://www.rferl.org/nca/features/1996/05/F .RU .96050813024533.html>. 
scene, such as Russia, Belarus, and Ukraine, and those in which former communists and former dissidents compete for political power, such as in the Baltics and most countries of central E urope.

\section{A. Czechoslovakia (The Czech R epublic and Slovakia)}

Czechoslovakia was one of the first countries to adopt a stringent lustration code. Passed by the Czech and Slovak National A ssembly on 0 ctober 4, 1991, the Lustration Law barred former Party officials, members of the People's Militia ${ }^{3}$ and members of the National Security Corps-as well as suspected collaborators-from holding a range of elected and appointed positions in state-owned companies, academia, and the media for a period of five years (until January 30, 1996). ${ }^{4}$ Parliament later extended the law to the year 2000, overriding a veto by President $\mathrm{V}$ aclav $\mathrm{H}$ avel.

The 1991 Lustration Law focused specifically on individuals whose names appeared in the files of the StB, the former Czechoslovak Secret Police. O riginally, the law also targeted "potential candidates for collaboration," yet this was so vague that in 1992 the Constitutional Court declared it illegal. The Court upheld all other provisions.

Under the law, former Communist officials and collaborators with the Secret Police were banned from

holding positions in the state administration at both the federal and the republican levels; the Czechoslovak A rmy (the rank of colonel and higher); the federal Security and Information Service; the federal intelligence agency; the federal Police; the O ffice of the President; the O ffice of the Federal A ssembly; the O ffice of the Czech N ational Council; the Office of the Slovak National Council; the offices of the federal, Czech and Slovak governments; the offices of the federal and republican Constitutional Courts; the offices of the federal republican Supreme Courts; and the Presidium of the Czechoslovak A cademy of Sciences; ... top positions in Czechoslovak, Czech and Slovak R adio and Television; ... the Czechoslovak Press A gency; ... top management positions in enterprises and banks owned by the state; to top academic positions at colleges and universities; and to judges and prosecutors.

Tens of thousands of people were affected. ${ }^{6}$

The international community has criticized the law on grounds that it discriminates in employment and violates human rights standards; specifically, it assigns collective guilt by prosecuting individuals solely on the basis of membership or affiliation. There was, however, a mechanism for individuals to appeal lustration decisions. Indeed, most of those who appealed cleared their names. In addition to the appeals process, individuals could file a legal action against the $M$ inistry of Interior for slander. ${ }^{7}$

3. The People's M ilitia was the para-military wing of Czechoslovakia's Communist Party.

4. The law applies to activities carried out in the service of the Party between 1948 and 1989.

5. Jiři Pene, Parliament Passes Controversial Law on Vetting Officials, in 2 TRANSITIONAL JUSTICE: HOW EMERGING DEMOCRACIES RECKON WITH FORMER REgIMES, COUNTRY STUdies 550-51 (Neal K ritz ed., 1995) [hereinafter 2 TRA NSITIONA L J U STICE ].

6. See id. at 553.

7. Between 1983 and 1996, 581 legal actions were brought against the M inistry. See U.S. DEP'T of State, The CZeCh Republic Country Report on Human Rights PRACTICES For 1996 (J an. 
1. The Czech Republic. On J anuary 1, 1993, the C zech and Slovak Federal Republic split into two countries. Lustration proceedings continued in the newly created Czech Republic under the same law that existed in Czechoslovakia. By A ugust of the same year, 210,000 people had been screened. ${ }^{8}$

O n J uly 9, 1993, the C zech Parliament passed the Law on the Illegitimacy of and Resistance to the Communist Regime. The law declared the former Communist Party "illegitimate" and "criminal," and attempted to honor those persons who "on the basis of democratic, moral or religious conviction" fought against the Communist Party. In a ruling issued in D ecember 1993, the Czech Constitutional Court upheld the Law. ${ }^{9}$ It remains to be seen how the Czech government will react to a recent Council of E urope's Parliamentary A ssembly criticism of the $\mathrm{C}$ zech lustration law. ${ }^{10}$

2. Slovakia. Vladimir M ečiar's newly independent government opposed the L ustration L aw and, in J anuary 1994, petitioned the Constitutional Court to overturn it. Though the Court rejected the petition, the law was never invoked, and remained dormant until it expired at the end of 1996.

On February 2, 1996, the Slovak National Council adopted a new law declaring the former Communist regime "immoral" and "illegal." "11 The law has yet to be reviewed by the Constitutional Court.

\section{B. H ungary}

In 1990, H ungary held its first free elections in forty years. The Communist Party, renamed the H ungarian Socialist Party, was soundly defeated and gained less than ten percent of the seats in the new Parliament.

The new government pushed for prosecution of individuals who had helped to crush the 1956 Revolution. A 1991 law attempted to restart the expired Statute of Limitations for selected crimes committed between 1944 and $1990 .{ }^{12}$ The Constitutional Court found the law to be unconstitutional. ${ }^{13}$ The same court, however, upheld a revised version of the law, which classified the 1956 crimes as "war crimes" and "crimes against humanity," neither of which were subject to a statute of limitations.

On March 9, 1994, two months prior to national elections, the Parliament adopted a lustration law ${ }^{14}$ that subjected approximately 12,000 "officials" to a

30, 1997).

8. See2 TRANSITIONAL J USTICE, supra note 5, at 534 (editor's introductory note).

9. See Czech Republic: Constitutional Court Decision on the Act on the Illegality of the Communist R egime (D ec. 21, 1993), reprinted in 2 TRA N SITIONA L J U STICE, supra note 5, at 620.

10. Radio Free E urope/Radio L iberty (radio broadcast, Sept. 23, 1997).

11. See Constitution Watch, 5 E. E UR. CONST. REV . 2, 26 (Spring/Summer 1996).

12. See2 TRANSITIONA L J U STICE, supra note 5, at 646 (editor's introductory note) .

13. See H ungary: Constitutional Court D ecision on the Statute of Limitations N o. 2086/A /1991/14 (M ar. 5, 1992), reprinted in 2 TRA NSITIONA L J U STICE, supra note 5, at 629.

14. See Law on Background Checks to be Conducted on Individuals Holding Certain Important 
screening process designed to determine whether they had collaborated with the former Secret Police. ${ }^{15}$ Included were members of Parliament and the Government; the President and Vice-Presidents of the Hungarian National Bank; ambassadors; army commanders; the presidents, vice-presidents, and editors of $\mathrm{H}$ ungarian Radio, $\mathrm{H}$ ungarian Television, and the $\mathrm{H}$ ungarian $\mathrm{N}$ ews Service; chiefs of police, presidents, deans, general directors, and department heads of state-owned universities and colleges; career judges; district attorneys; editors at daily newspapers and weekly magazines; directors of state-owned agencies; and managers of state-owned banks, financial institutions, and insurance companies.

In all, more than twenty-five categories of high-ranking posts are subject to the new law. The screening procedure charges two panels with responsibility to examine the secret files of all persons under investigation; the panels are to complete their work between J uly 1, 1994 and J une 30, 2000. O n J uly 1, 2030, the list of agents and all documents used are to be made public. Information about any public official screened between 1994 and 2000 will be made public thirty years after the panel's ruling. ${ }^{16}$

The Constitutional Court struck down several provisions of the M arch 1994 law, finding them vague and arbitrary. To remedy these deficiencies, Parliament enacted a new law on J uly 3, 1996, which stipulates that all persons born before February 14, 1972 must be screened before taking an oath before Parliament or the President. The central purpose of the screening is to assess whether the official worked for the internal state security service. If an official is found to have carried out activities for the agency, he or she will be asked to resign within thirty days. If the official does not resign, the panel's findings are to be published in the H ungarian O fficial G azette.

In A pril 1997, several deputies came under scrutiny for being suspected as having worked as secret agents. ${ }^{17}$ Two screening committees examined the records of approximately 600 officials to ascertain whether they had been employees of the counter-intelligence department of the M inistry of Interior. ${ }^{18}$ They were also investigated to determine whether they had collaborated in exposing insurgents of the 1956 uprising or whether they had links with the preCommunist A rrow Cross fascist party. ${ }^{19}$ Later, Judit C sehak, deputy prime minister in H ungary's last Communist government, admitted that, as a member of the former H ungarian Socialist W orker's Party's politburo, she had access to state security reports. ${ }^{20}$ She was called on to resign by the panel of judges who

Positions (Law N o. 23) (M ar. 8, 1994), reprinted in 2 TRA NSITIONA L J U STICE, supra note 5, at 418.

15. See 2 TRANSITIONA L J USTICE, supra note 5, at 646 (editor's introductory note).

16. See E dith O Itay, Hungary's Screening L aw, in 2 TRA NSITIONA L J U STICE, supra note 5, at 664 .

17. Radio Free E urope/Radio L iberty (radio broadcast, M ay 12,1997 ).

18. Id.

19. Id.

20. Id. 
screen parliamentary deputies. ${ }^{21}$

C. A Ibania

A lbania began restricting the political participation of former Communist Party members soon after the March 1992 general elections. Once the Democratic Party had firm control of the government and legislature, the "Iustration" process began.

The J uly 1992 Law on Political Parties prohibited the creation of "any party or organization with an antinational, chauvinistic, racist, totalitarian, Fascist, Stalinist, 'Enverist' or Communist, or Marxist-Leninist character, or any political party with an ethnic or religious basis." ${ }^{22}$ M embers of the Communist Party attempted, but failed, to overturn the law in a series of 1993 court proceedings.

Between 1992 and 1994, the government brought charges against more than seventy former Communist officials. ${ }^{23}$ In D ecember 1993, ten senior officials were each fined the equivalent of $\$ 60,000$ and sentenced to prison. ${ }^{24}$

In M ay 1993, A Ibania's Constitutional Court struck down the country's first lustration law designed to screen and revoke the license of any lawyer with party affiliation or connections to the former Secret Police. ${ }^{25}$ Under the law, advocates would not be licensed if they were found to be any of the following: a former State Security O fficer; member of the Committee of Labor Party of A lbania; investigator, prosecutor, or judge in "special or stayed political trials"; or a prison or internment camp employee. Licenses could also be denied to persons found to have used physical or psychological force during an investigation.

In 1995, Parliament adopted two new laws. The first was the $L$ aw on $\mathrm{G}$ enocide and Crimes against $\mathrm{H}$ umanity Committed during the Communist R egime for Political, I deological, and R eligious M otives ("G enocide Law"). ${ }^{26}$ The second was the $L$ aw on the $V$ erification of the M oral Character of $O$ fficials and Other Persons Connected with the Defense of the Democratic State

21. Radio Free E urope/Radio L iberty (radio broadcast, J une 13,1997 ). A nother "casualty" of the lustration law, I mre Simon, a Socialist deputy of the national parliament, announced on A ugust 6, 1997 that he would resign his post after a panel of judges reported they had found information that he had collaborated with the communist Secret Service. Id. (A ug. 7, 1997). In A ugust 1997, J ozsef Torgyan, chairman of the Independent Smallholder's Party, was finally exonerated from charges brought against him for complicity in secret agent activities during the communist era. See <http://www.rferl.org/newsline/1997/150897.html>.

22. U.S. Dep't of State, Albania Country Report on human Rights Practices for 1996, at 822 (J an. 30, 1997) [hereinafter A LBANIA REPORT].

23. Seeid.

24. See Commission on Security and Cooperation in E urope, H uman Rights and D emocratization in E urope, in 2 TRANSITIONA L J USTICE, supra note 5, at 729-34.

25. See Kathleen Imholz, A L andmark Constitutional Court Decision in Albania, in 2 TRANSITIONAL JUSTICE, supra note 5, at 724.

26. A Ibanian Law on $G$ enocide (unofficial translation on file with author); see also Berisha Speaks on L aw on G enocide, Dayton A ccord, F.B.I.S. D A ILY R EPORT E. E UR., D ec. 11, 1995, at 21. 
(“Lustration L aw"). ${ }^{27}$

The $\mathrm{G}$ enocide $\mathrm{L}$ aw prohibits persons with ties to the regime prior to $\mathrm{M}$ arch 1991 from holding selected positions in the government, parliament, judiciary, or mass media until the year $2002 .^{28}$ The law applies to former members of the Politburo and Central Committee, ministers, parliamentary deputies, presidents of the Supreme Court, former Secret Police agents and informers. The law passed with the votes of 74 out of 140 legislators. ${ }^{29}$ Opposition parties denounced the law as vengeful and called it an attempt to close them out of Parliamentary elections. ${ }^{30}$

The L ustration L aw permits the government, under the auspices of a newly created Special V erification Commission, to examine former Secret Police files in order to assess the applicability of the G enocide Law. ${ }^{31}$ A candidate cannot run for office without clearance from the Commission. ${ }^{32}$ The opposition parties were specifically excluded from the selection process, which ultimately was criticized for placing all control in the executive branch, conducting proceedings in closed session, and relying solely on secret files.

On January 31, 1996, A Ibania's Constitutional Court upheld most provisions of the Genocide Law and the Lustration Law, though it did strike down certain questionable provisions that subjected journalists at private newspapers to screening. ${ }^{33}$

A s a result of the laws, a person may run for elected office only after being "cleared" in a long and arduous administrative procedure. ${ }^{34}$ A s it happened, the Commission banned 139 candidates from participating in the flawed M ay 1996 parliamentary elections. ${ }^{35}$ Only fifty-seven appealed to the Court of Cassation; the Court overturned seven of those decisions. ${ }^{36}$ The international community criticized the process on the ground that it failed to grant prospective candidates the right to due process. ${ }^{37}$

The new laws also permitted the government to imprison former President R amiz A lia a second time. In part due to changes in the criminal code, A lia had received partial amnesty and was released from prison in July 1995.

27. See Constitution Watch, supra note 11 , at 2; see also A ssembly A pproves $L$ aw Screening Senior Officials, F.B.I.S. DAILY REPORT E. EUR., Dec. 6, 1995 at 1 . The screening law has also been translated as "Law on the Control of the Figure of Senior O fficials and O ther Persons R elated to the Defence of the D emocratic State."

28. See A LBANIA REPORT, supra note 22, at 816-17.

29. See O M R I D aily D igest (Sept. 26, 1995).

30. See id.

31. The Commission consists of seven representatives: two appointed by the Council of M inisters, and one each appointed by the $M$ inister of J ustice, $M$ inister of D efense, $M$ inister of the Interior, National Intelligence Service, and the Parliament. See id. at 4.

32. See Constitution Watch, supra note 11 , at 3.

33. See id.

34. See id.

35. Of those banned, 45 were members of the Socialist Party, 23 were Social D emocrats, 11 were from the Democratic A lliance, 13 from the Republic Party, 3 from the Democratic Party, and the remaining from minor parties. See A Ibania R eport, supra note 22, at 817.

36. See id.

37. See id. 
Without regard to double jeopardy, A lia was subsequently re-arrested and charged with crimes against humanity. A lia left prison M arch 14, 1997, along with over 600 other prisoners, when guards deserted the central prison in Tirana. $^{38} \mathrm{H}$ is trial on charges of "genocide and crimes against humanity" was adjourned on J une 9, 1997, when he failed to appear in court. ${ }^{39}$

Since $M$ arch 2, 1997, A Ibania has been under a state of emergency. ${ }^{40}$ Fatos $\mathrm{N}$ ano, former chairman of the Socialist Party who had been jailed since 1993, was released in $\mathrm{M}$ arch, seemingly along with all other prisoners both political and criminal. ${ }^{41}$ The lustration committee that investigates candidates before they may register to vote was late in issuing its reports and delayed the J une 1997 elections. $^{42}$ R egardless of the fact that the lustration committee had disqualified 31 legislative candidates because of their links to the Sigurimi (secret police), ${ }^{43} \mathrm{~N}$ ano and the Socialist Party were returned to power by the June elections. ${ }^{44}$ On September 29, 1997, the Albanian Supreme Court overturned the convictions of all thirty-two former Communist officials who had been sentenced to prison for crimes against humanity. ${ }^{45} M$ any of the former officials were also prosecuted for abuse of power. ${ }^{46}$ Four of those are serving prison terms. ${ }^{47}$

\section{Bulgaria}

A Ithough the Communist Party was formally banned in 1990, its successor party, the Bulgarian Socialist Party ("BSP"), has played a pivotal role in Bulgarian politics. The BSP won a narrow majority in the new $\mathrm{G}$ rand National A ssembly elected in J une 1990. The 1991 parliamentary elections then turned in favor of the U nion of Democratic Forces ("UDF"), which held power until 1994. A fter failing in a 1993 attempt to declare the BSP illegal, ${ }^{48}$ the UDF was finally defeated by the BSP and its two coalition partners, who won an absolute majority in the D ecember 1994 pre-term elections.

D espite the establishment of a Special V erification Commission in 1990, the aggressive pursuit of former Communist collaborators was blocked regularly by members of Parliament and government ministries. ${ }^{49}$ Ultimately, the

38. See <http://www.rferl.org/nca/news/1997/N .R U .970314153730.html>.

39. See <http://www.rferl.org/nca/news/1997/N.RU.970609143904.html>. As of J une 9, 1997, A lia's whereabouts, and that of his co-defendants, former interior ministers Simon Stefani and Hekuran I sai, are unknown. See id.

40. See Constitution Watch, 6 E. E UR. CONST. REV. 2 (W inter 1997).

41. Seeid.

42. See Radio Free E urope/Radio L iberty (radio broadcast, J une 11, 1997).

43. See Radio Free E urope/Radio L iberty (radio broadcast, J une 16, 1997).

44. See Constitution Watch, supra note 40 , at 2.

45. See Radio Free E urope/Radio L iberty (radio broadcast, Sept. 30, 1997).

46. See id.

47. See id.

48. On M arch 11, 1993, the Bulgarian Supreme Court rejected a lawsuit that sought to declare the BSP illegal. See 2 TRANSITIONA L J USTICE, supra note 5, at 696.

49. See J ózef Darski, Police A gents in the Transition Period, in 2 TRA NSITIONA L JUSTICE, supra note 5 , at 696 . 
Communist-dominated Parliament prevailed in sealing the files of secret collaborators for thirty years. ${ }^{50}$

When the U DF came into power in 1991, there was a renewed call to purge government and selected non-government institutions of former Communist members. Four proposed lustration laws, ${ }^{51}$ submitted to Parliament in 1992, would have prevented anyone in a leadership position between September 9, 1944 and J anuary 1, 1990 from holding public office for five years. ${ }^{52} \mathrm{~N}$ ot one of the four draft laws made it to a vote. The primary obstacle was a Constitutional Court ruling on several "lustration restrictions" added to the Banking $L$ aw ${ }^{53}$ and the "Pension L aw," ${ }^{54}$ passed on M arch 4, 1992 and J une 12, 1992, respectively. O n J uly 27 and July 29, 1992, the Court held the restrictive provisions unconstitutional. ${ }^{55}$

The Constitutional Court did, however, uphold another lustration law-the $L$ aw on the Temporary Introduction of A dditional R equirements for $M$ embers of the Executive Bodies of the Scientific Organizations and the Higher Certifying Commission ("the Panev Law"). The law required screening of all persons aspiring to positions in the executive bodies of scientific organizations. Candidates were required to prove that they were not ranking members of the Communist Party. ${ }^{56}$

On February 19, 1993, the Constitutional Court upheld, in a six-to-five decision, the law's constitutionality, ruling that the law simply required "additional" qualifications. The Court's decision, which seemed to contradict its earlier rulings of proposed lustration laws, was criticized by international

50. See id. at 697.

51. The Law on Overcoming the Consequences of Communist Rule, the Law on Recommunization in the Sphere of Government, the Public Servants Act, and the Law on Democratization. See 2 TRA NSITIONA L J U STICE, supra note 5, at 698-99.

52. Persons affected were former members of the Politburo, chairs and deputy chairs of the State Council and of the National A ssembly, prime ministers and vice-prime ministers, first secretaries and secretaries of district and regional committees of the Communist Party, leaders of the Bulgarian Trade U nion, leaders of the Communist $Y$ outh League, and lower-level Communist Party officials. See id. at 698.

53. Transitional and Concluding Provisions of the $L$ aw for $B$ anks and Credit, OFFICIA L G A ZETTE, No. 25, 1992, reprinted in 2 TRA NSITIONA L J USTICE, supra note 5, at 293.

54. Pension Law, OfFICIA L GAZETTE, No. 52, 1992.

55. Seeid.

56. This included members or candidate members of the Political Bureau or the Secretariat of the Central Committee of the Bulgarian Communist Party ("BCP"); secretaries or members of the regional, city, community, county, or district committees of the $B C P$; those who held positions before 1989 which were accountable to either the Political Bureau or the Secretariat of the Central Committee of the BCP; those who were staff or voluntary collaborators of the State Security or the Security and G uard D epartments; those who were on the teaching and research staff of the A cademy for Social Sciences and Social Management and its branches; those who taught $H$ istory of the Communist Party of the Soviet U nion, $\mathrm{H}$ istory of the BCP, M arxist-Leninist Philosophy, Political E conomy, Scientific Communism, or Party Building; those who were political officers or deputy commanding political officers or who held positions in the political headquarters of the A rmed Forces; and those who have been secretaries or members of party committees of the B CP in the higher schools or academies, or secretaries of the Party organizations of the BCP in the faculties, scientific institutes, and other scientific organizations, or members of personnel commissions under the party committees of the higher schools, academies, or other scientific organizations. See 2 TRANSITIONAL JUSTICE, supra note 5, at 700-01. 
human rights organizations and has caused great consternation in the governing bodies of B ulgarian academic institutions. ${ }^{57}$

A number of former Communist leaders have been charged with alleged abuses during the Communist regime. The existing twenty-year statute of limitations for certain categories of crimes was revised retroactively to thirtyfive years. In A pril 1996, the Prosecutor General's Office suspended the investigation of forty-three cases involving Communist Party leaders who were indicted in 1994. The cases were suspended because many of the accused held immunity as deputies of the BSP. ${ }^{58}$

In an electoral rejection of the formerly communist Socialist Party, which had controlled the country since 1989, the UDF regained power in the Spring, 1997 elections. $^{59}$ The Bulgarian Cabinet approved a draft law on Communist police files on J uly $7,1997 .^{60}$ The bill would make mandatory the opening of all files of members of high government officials and give them one month to admit their past activities. ${ }^{61}$ The bill contemplated making the files available to the general public after one year. ${ }^{62}$ O n J uly 30, 1997, the bill was adopted into law. ${ }^{63}$ The opposition Socialist Party, the A lliance for National Salvation, and the Bulgarian Business B loc joined forces to file an appeal to the Constitutional Court on A ugust 8, 1997. ${ }^{64}$ The appeal questioned the constitutionality of the law as it creates a commission headed by the Minister of the Interior to examine the files of high-ranking officials. ${ }^{65}$ The appeal warned, for example, the normal functioning of the state would be jeopardized if the files of the president were to reveal he had collaborated with the former Communist security services. ${ }^{66}$ The Bulgarian Constitutional Court has recently rejected the appeal made by opposition party deputies to declare the law opening Secret Police files unconstitutional. ${ }^{67} \mathrm{H}$ owever, the Court did support their claim that the law could jeopardize the ability of the president, vice president, and members of the Constitutional Court to function and ruled that the files of individuals in those positions should not be opened. ${ }^{68}$

Lustration efforts continue in Bulgaria. Most recently, for example, the

57. See D ecommunization in Bulgaria, in 2 TRA NSITIONA L JUSTICE, supra note 5, at 702-04.

58. See U.S. Department of State, Bulgaria Country Report on human Rights PRACTICESFOR 1996, at 879 ( $\mathrm{J}$ an. 30, 1997).

59. See News in B rief, CHRISTIA N SCIENCE MONITOR, A pr. 21, 1997, at 2.

60. See Radio Free E urope/Radio L iberty (radio broadcast, J uly 8, 1997).

61. See id. The bill covers members of parliament, ministers, senior government officials, and high-ranking judges. Those who admit Communist activity before the month deadline will not have their names read out in Parliament and will not be forced to resign their posts. Id.

62. Seeid.

63. See Radio Free E urope/Radio L iberty (radio broadcast, A ug. 1, 1997). The opposition Socialist Party deputies protested by walking out of the chamber and vowing to contest the law before the Constitutional Court. The U NS (third-largest faction) abstained from the vote. Id.

64. See Radio Free E urope/Radio L iberty (radio broadcast, A ug. 11, 1997).

65. See id.

66. See id.

67. See Radio Free E urope/Radio L iberty (radio broadcast, Sept. 23, 1997).

68. See id. 
government approved a draft law on public administration prohibiting former members of the Communist nomenklatura from taking high positions in the civil service for five years. ${ }^{69}$

\section{E. The B altics}

1. L ithuania. Lithuania declared its independence on $M$ arch 4,1990 . The problem of how to handle K G B collaborators caused immediate concern, and the government finally declared, on October 12, 1991, that former KGB employees and collaborators could not hold local or national government posts for five years. ${ }^{70}$

A 1991 decree banned the Communist Party and ordered the confiscation of all property held by the Lithuanian Communist Party ("LCP") and its affiliated organizations to be confiscated. It also called for a special parliamentary commission to review the information contained in secret K G B files. The magnitude of potential lustration proceedings is revealed in the number of files that Moscow agreed to turn over to Lithuania. The first shipment alone included 2,400 boxes containing 31,241 screening files and 11,558 interrogation files. ${ }^{71}$

D espite the fact that $L$ ithuania's transition government required political candidates to disclose past connections to the KGB or Communist Party, ${ }^{72}$ the Lithuanian Democratic Labor Party ("LDLP")-the successor to the LCPstood in the O ctober 1992 parliamentary elections and easily won a majority of seats. The government's subsequent attempts to prevent the newly elected parliamentarians from taking office was blocked by the Supreme Court, ${ }^{73}$ and the LD L P successfully formed a new G overnment.

2. L atvia. In January 1991, the newly independent government of Latvia outlawed the Latvian Communist Party. In late 1993, the Law on R egistering Public O rganizations was amended to bar any public organization, specifically "Communist" and "Nazi," whose "activities would contravene the Constitution." 74

In 1995, Parliament adopted a law preventing members of banned organizations not fluent in Latvian from holding state office. The law also barred the candidacy of any citizen who remained active in the Communist

69. See Radio Free E urope/Radio L iberty (radio broadcast, Sept. 29, 1997).

70. See Decree Banning K G B E mployees and Informers from G overnment Positions (D ecree No. 418) (O ct. 12, 1991), reprinted in 2 TRA NSITIONA L J USTICE, supra note 5, at 427.

71. See id.

72. See Law on the Verification of Mandates of those Deputies A ccused of Consciously Collaborating with Special Services of Other States (Law No. 1-2115) (D ec. 17, 1991), reprinted in 2 TRANSITIONAL JUSTICE, supra note 5, at 428.

73. Seeid. at 765 .

74. U.S. Department of State, LatVia Country Report on human Rights Practices FOR 1996, at 1009-11 (J an. 30, 1997) [hereinafter LATVIAN REPORT]. 
Party or other "post-Soviet organizations" after January 13, $1991 .{ }^{75}$ A dditionally, convicts and non-citizens would be ineligible for the presidency. The law was pushed through Parliament in response to the candidacy of former Party leader A Ifred Rubiks, who was then serving an eight-year sentence for attempting to overthrow the Government in 1991. Just five days before the J une 18, 1995 elections, the law passed by a slim margin. It did not, however, legally disqualify R ubiks because it was deemed inconsistent with A rticle 69 of the Latvian Constitution. ${ }^{76}$ Nevertheless, several former candidates from the Socialist Party (including R ubiks) were tried for making false statements about their past during the run-up to the 1995 elections. ${ }^{77}$

In November 1996, the Saeima adopted a new law restricting anyone associated with the Communists from running in the March 1997 local elections.

Following admission to the Council of Europe in February 1995, Latvia signed the European Convention on Human Rights. Comparing the Convention with domestic law, the Saeima rejected a draft law submitted by the Latvian National Independence Movement ("LNIM"). The LNIM proposal would have allowed publication of, and public access to, K G B agent "dossiers." ${ }^{78}$ The files, deemed to contain insufficient information, were considered flawed. A lthough many doubt Moscow's intention to deliver the official dossiers, ${ }^{79}$ the Saeima nevertheless appears to be waiting for these documents. The lustration issue thus remains on the agenda.

In M arch 1996, President U Imanis received an appeal, signed by thirteen members of the Council of Europe's Parliamentary A ssembly and a group of $L$ atvian M Ps, to pardon former Party L eader A Ifred R ubiks. R ubiks has said that he did not want the amnesty that was petitioned for him by Saeima and Council of Europe deputies and also by the R ussian State Duma, because he believed the illegal character of his convictions would be recognized. ${ }^{80}$ R ubiks was nominated as a candidate for president in the J une 1996 elections. ${ }^{81}$ The J une 1996 elections saw G untis U Imanis re-elected as president, but R ubiks, still in prison, did receive the votes of five deputies. ${ }^{82}$

3. Estonia. Estonia has effected lustration primarily through its Citizenship Law and Local Election Law. The Citizenship Law, enacted in February 1992, was a readoption of the 1938 Citizenship Law. A ccording to the

75. See id.

76. A rticle 69 (Promulgation) reads, "[t]he President of the State shall promulgate laws passed by the Parliament not before the seventh and not later than the twenty-first day after their adoption. If no other term be fixed, the laws shall come into force fourteen days afgter their promulgation." LAT. CONST. A rt. 69 (emphasis added).

77. See LATVIAN REPORT, supra note 74.

78. See Constitution Watch, supra note 11 , at 14.

79. See id.

80. See Saulius G irnius, <http://www.rferl.org/newsline/1996.04/010496.html>.

81. See Peter Z vagulis, <http://www.rferl.org/nca/news/1996/05/N .R U .96052017174651.html>.

82. See Saulius G irnius, <http://www.rferl.org/newsline/1996/06/3-CE E /cee-180696.html>. 
Law, anyone born after 1940 to parents who were citizens is automatically a citizen; the parents do not have to be ethnic Estonians. For residents to be naturalized, the law stipulated that they speak Estonian, fulfill a two-year residency requirement, and submit to a one-year waiting period. ${ }^{83}$

In J anuary 1995, Parliament passed a revised Citizenship L aw extending the residency requirement from two to five years, and requiring a demonstration of knowledge about the Constitution and Citizenship Law. Persons in legal residence prior to July 1, 1990 are exempt from the residency and waiting period requirements. ${ }^{84}$ Finally, the new law permits the government to waive the language requirement in selected circumstances. ${ }^{85}$

The current law states that persons are ineligible for naturalization if they filed false dates or documents, acted unlawfully or in disregard of the constitution, acted against the state and its security, was sentenced to crimes punishable for more than one year, worked in the intelligence or security service of a foreign state, or served as a career soldier in the armed forces of a foreign state. ${ }^{86}$

By M ay 9, 1997, the government had published, in the official journal, Riigi Teataja, two lists of former KGB informers who had failed to report their role by $A$ pril 1, 1996. ${ }^{87}$ A s of J une 18, 1996, forty-one persons had been refused residence and work permits because they have a criminal record, were employees of the former K G B , or gave false information about themselves. ${ }^{88}$

\section{F. Poland}

Between 1990 and 1992, the Sejm introduced a number of lustration proposals, none of which were enacted. It was relatively late, in 1996, that Poland began working on a comprehensive lustration law. Five drafts were submitted separately by political parties. The drafts differ in the categories of persons subject to screening and due process protection. Parliament established a special commission to consolidate the various versions into a single draft.

The current draft states that the President, M Ps, judges, prosecutors, and persons appointed to senior posts by the President, Parliament, the Prime $M$ inister or the Prosecutor $G$ eneral are subject to screening. The individuals occupying these positions must declare whether they collaborated with the former minister of public security, the Secret Police, or the military police. ${ }^{89}$

On March 26, 1997, the Parliamentary Special Commission approved

83. See U.S. Department of State, Estonian COUNTRY REPORT ON Human Rights PRACTICESFOR 1996, at 931 ( $\mathrm{J}$ an. 30, 1997).

84. See id.

85. For instance, a person who has elementary E stonian language skills or higher education or has performed valuable service to E stonia may be exempt. See id.

86. See id.

87. See Radio Free E urope/Radio L iberty (radio broadcast, M ay 12,1997 ).

88. See Girnius, supra note 82.

89. See id. 
amendments to the L ustration Law submitted during the legislation's second reading in the Sejm. In M ay 1997, the Sejm passed the law which provides for the screening and vetting of people seeking public office to ensure they are not former collaborators with the Communist-era Secret Services. Top officials and candidates for office are also affected by the law. R ectors, chief editors, managers, and others who were required to report on their past activities with the Secret Police were excluded from the screening procedure. Intelligence and counterintelligence officials would still be required to go through the screening process. The Commission rejected an amendment defining what constituted collaboration with the Secret Police.

The amendments to the L aw on L ustration entered into force on A ugust 3, $1997 .{ }^{90}$ The Law created the Lustration Court to examine complicity with the Secret Police. ${ }^{91}$ The Lustration Court's mandate is to verify the declarations of top officials ${ }^{92}$ as to whether or not they served or collaborated with the Communist-era Secret Police. The Court, made up of appellate and provincial court judges, will have unlimited access to civil and military archives. ${ }^{93}$ The target of the screening wil have the right to counsel and to appeal the decision of the Lustration Court. ${ }^{94}$ Those found to have given false statements will be banned from public office for ten years ${ }^{95}$ and can also be sentenced to up to five years in prison for perjury. ${ }^{96}$

A s of January 1, 1997, the Interior M inistry archives were declassified. Thus, documents on file as of December 1965 have been declassified. E ach year on J anuary 1, additional files (thirty years past) will be declassified. O nce declassified, materials will be made available to courts, prosecutors' offices, and the public. Files that document the activities of Secret Police collaborators will not be declassified, except in special murder investigations, such as the 1970 killing of student activist Stanislaw R yjas, where prosecutors will be given access to the files. In response to the requirement that candidates declare whether or not they had collaborated with the Communist-era Secret Service, in the A ugust 1997 campaigns, Solidarity E lectoral A ction ("A W S") candidates all denied collaboration. ${ }^{97}$ However, some Democratic Left A lliance ("SLD")

90. Radio Free E urope/Radio L iberty (radio broadcast, A ug. 5, 1997).

91. Id.

92. Including the president, ministers, provincial governors, deputies, senators, judges, executive directors of provincial offices, and the heads of public TV, radio, and press agencies. Id. Excluded from the screening procedure will be university presidents, chief editors, managers, and others who were obliged by law to give information to the Communist-era secret police. See N ews from Poland, Newsletter of the Polish E mbassy of the Republic of Poland (May 1997), $<$ <ttp://www.polishworld.com/polemb/news/597/screen/htm>.

93. See Constitution Watch, supra note 40 , at 22 . The screening court is composed of 21 judges ( 7 from the Supreme Court, 7 from the Courts of A ppeal, and 7 from provincial courts). Id.

94. See id.

95. See id.

96. See id. Statements found to be false will be published in the official government gazette as well. Seeid.

97. See <http://www.rferl.org/newsline/1997/08/150897.html>. 
candidates have admitted to cooperating with the Secret Services. ${ }^{98}$

\section{G. Romania}

In M arch 1997, the R omanian Parliament proposed a draft law on A ccess of Former Communist Officials and Members of the Totalitarian Regime to Public and Political Positions. Persons who held major positions in the Communist Party, the executive and judiciary, the G reat National A ssembly, the army, or the former office of the Securitate (secret police) at any time between M arch 6, 1945 and D ecember 22, 1989 cannot, for the next eight years, hold the following positions: prime minister, member of government, public prosecutor, president of the court, governor, governor deputy, director of the national television company, or ambassador. In addition, these people cannot be elected for the Constitutional Court, Supreme Court, Superior Council of Magistrates, Romanian A cademy, or the Audio-Visual Media National Council.

A ccording to the Draft, "major positions" within the Communist Party include members of the Central Committee (at the regional, district, and county levels), members of government, members of the judiciary, officers of the securitate, and officers of the army. ${ }^{99}$

Persons who, irrespective of their positions, were arrested, convicted, or suffered any other consequence due to "anti-Soviet" or "anti-Communist" opinions between M arch 6, 1945 and December 22, 1989 are exempted from the provisions of the proposed law. ${ }^{100}$

Persons holding any of the positions mentioned in the draft law must submit a statement attesting that they did not collaborate with the former Communist regime. Members of the Romanian Intelligence Service, the Ministry of Internal A ffairs, or other selected government institutions must answer within thirty days upon being notified. ${ }^{101}$

A the time of this writing, the draft law had not been adopted and, in fact, is expected to run into difficulties. N ot only is it inconsistent with R omania's Election Law, it also appears to violate A rticle 16 of the Constitution, which states that "[a]Il citizens are equal before the law and public authorities, without privilege or discrimination."

H. Russia

On A ugust 19, 1991, a senior group of Communist Party, military, and K G B authorities attempted a coup d'etat against Boris $Y$ eltsin, the democratically elected president of R ussia. Soon after the failed coup, $Y$ eltsin issued several decrees that banned the Communist Party and started the process of

98. See id.

99. See Draft Law Regarding the Access of Former Communist Officials and Members of Totalitarian R egimes to Public and Political Positions (unofficial translation on file with author).

100. See id.

101. See id. 
confiscating its assets. The decree stated that the M inistry of Internal A ffairs and the Procuracy were to investigate cases of "anti-constitutional" activity by organs of the Communist Party. A II property and monetary resources of the bodies and organizations of the Communist Party were to be kept safe "until adoption of a final decision by the judicial bodies." ${ }^{102}$ In another decree, Y eltsin acted to "put a stop to the activities of the Communist Party and to dissolve their organizational structures." 103

The decrees were challenged in Russia's new Constitutional Court. On November 30, 1992, the Court ruled that local branches of the Communist Party could be re-established, even though the national Communist Party was banned.

Generally, efforts to use Secret Police files to screen and purge former Communist Party officials have not been adopted in R ussia. Though members of Parliament have debated a draft lustration law, it has not been passed. A nother proposed law banning former Party officials from high level government positions-such as teaching in universities or secondary schools, or holding management positions in the media-was presented to the Parliament, but it too was defeated.

The R ussian parliament did adopt several laws making it a criminal offense to identify KGB collaborators. O ne law bans the exposure of KGB agents. A nother protects the status of individuals who collaborated with the KGB. Perhaps the most interesting law was one that classified information about persons "confidentially cooperating" with the Russian Foreign Intelligence Service as a "state secret." ${ }^{104}$

Some members of the Constitutional Court have challenged any measure that would "counter the unconstitutional and unlawful activities of the Communist Party," since it would "grossly violate" the Court's 1992 decision. The government nevertheless has begun the process of reviewing and releasing classified documents held by the Communist Party and the K G B. ${ }^{105}$

\section{U kraine}

U kraine declared its independence on A ugust 24, 1991. It is only recently that calls have been made to restrict the political activity of former Communist Party officials. By J une 26, 1996, the U krainian national democratic forces had collected more than 2 million signatures for a petition to ban the Communist Party. The petition charges that the Communist Party "deliberately" tried to sabotage the new Constitution because it opposed U krainian independence. ${ }^{106}$

The Ministry of Justice has the authority to "warn" or "fine" a political

102. Seeid.

103. Decree on the A ctivities of the Communist Party of the Soviet U nion and the Communist Party of the Russian Soviet Federated Republic. (No. 169) (Nov. 6, 1991), reprinted in 2 TRANSITIONAL JUSTICE, supra note 5, at 434.

104. See id.

105. See id.

106. OMRI Daily Digest (J une 26, 1997). 
party for "illegal activities" if it violates the Law on Public O rganizations. The Ministry used this authority when the Communist Party began collecting signatures for a referendum in support of socialism and reintegration with the former Soviet U nion.

\section{J. Belarus}

Belarus has a constitutional government, but all power lies with the executive branch and President A leksandr L ukashenko. President L ukashenko is a "non-party" former Communist. Former Communists hold extraordinary influence in Belarus, where not a single member of the nationalist opposition gained a seat in the 1995 Parliamentary elections. No lustration laws exist in Belarus.

K. Central A sian R epublics: K azakstan, K yrgyzstan, Tajikistan, and U zbekistan

The Kazakstani Communist Party came under government scrutiny in March 1996 after sponsoring unsanctioned rallies and demonstrations in support of the R ussian D uma's vote to nullify the 1991 accords that disbanded the Soviet U nion. The G eneral Prosecutor's office called for the suspension of all Communist Party activities until the Party amended its charter (which calls for reconstitution of the Soviet Union) to recognize the sovereignty of Kazakstan. Several local Party chapters were fined and the National Party organization had difficulty renewing its registration. In November 1996, the Communist Party revised its charter and acknowledged Kazakstani sovereignty. There is no lustration law in Kazakstan.

In K yrgyzstan, the Communist Party was dissolved in 1991 and revived as the Party of Communists of K yrgyzstan in 1992. There is no lustration law in $\mathrm{K}$ yrgyzstan, and there are no lustration laws in Tajikistan and U zbekistan.

\section{III}

\section{CONCLUSION}

Surely the implementation of lustration legislation is politically motivated. But there are other motives at work as well: a desire for accountability, restitution, rehabilitation, and even revenge. ${ }^{107}$ The interplay of the political ebb and flow and these motives drive legislation that looks, as is apparent from this overview, quite unique to each of the former communist states. While the need to come to terms with the past is surely great, only time will tell whether the process of lustration, which has been criticized as more political than judicial, ${ }^{108}$ will enhance or diminish the growth of democratic institutions of these transitional states.

107. See J.H. Brown, Goodbye (and Good Riddance?) to De-Communization, 4 TrAnsitions 28 (1997).

108. See id. 